\title{
Acute Disseminated Encephalomyelitis in COVID-19: presentation of two cases and review of the literature
}

\author{
Encefalomielite disseminada aguda associada a COVID-19: relato de dois casos e \\ revisão de literatura
}

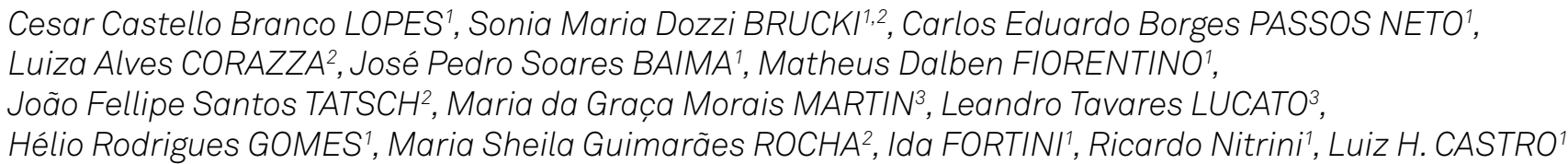

\section{ABSTRACT}

Background: Neurological manifestations of COVID-19 are still incompletely understood. Neurological manifestations may be due to direct viral effect on neurons and glial cells, to an immune-mediated response to the virus, or to a hypercoagulable state and associated endothelial damage, as well as to severe systemic disease with prolonged intensive care unit stay. Objective: To describe two patients with severe SARS-CoV-2 infection and delayed recovery of consciousness after sedation withdrawal, in whom MRI disclosed multifocal white matter brain lesions, compatible with the diagnosis of acute disseminated encephalomyelitis. Methods: Observational report of two cases of severe COVID-19 infection in patients from two tertiary hospitals in São Paulo, Brazil. Results: These patients underwent neurologic and systemic evaluation for delayed awakening after sedation withdrawal. MRI displayed multifocal centrum semiovale lesions, suggestive of demyelinating inflammation. Cerebrospinal fluid (CSF) polymerase chain reaction (PCR) for SARS-CoV-2 was negative in both cases. Conclusion: A recurrent pattern of multifocal white matter lesions can occur in COVID-19 patients, possibly associated with delayed awakening. Additional studies are necessary to elucidate the role of the viral infection and of inflammatory and immune-mediated associated changes in neurological manifestations of COVID-19.

Keywords: Neurology; Coronavirus Infections; Encephalitis; Central Nervous System Infections; Demyelinating Diseases.

\section{RESUMO}

Introdução: As manifestações neurológicas causadas pela COVID-19 ainda não estão completamente elucidadas. 0 comprometimento neurológico pode decorrer de um efeito viral direto em neurônios ou em células gliais, a efeito imunomediado em resposta à infecção viral, ou de um efeito secundário a estados de hipercoagulabilidade e danos endoteliais, assim como decorrente de complicações sistêmicas graves relacionadas a cuidados intensivos prolongados na unidade de terapia intensiva. Objetivo: Descrever dois pacientes com recuperação tardia do nivel de consciência após a retirada da sedação associados à infecção grave pelo SARS-CoV-2, que apresentaram lesões multifocais de substância branca, compatíveis com o diagnóstico de encefalomielite disseminada aguda. Métodos: Estudo observacional, com relato de dois casos de infecção grave pela COVID-19, em dois hospitais terciários na cidade de São Paulo, Brasil. Resultados: Os pacientes foram submetidos à investigação sistêmica e neurológica para avaliação de estado alterado de consciência após retirada de sedação. A ressonância magnética de crânio evidenciou lesões multifocais no centro semioval, sugestivos de processo inflamatório desmielinizante. Análise liquórica evidenciou PCR negativo para SARS-CoV-2 em ambos os casos. Conclusão: Lesões multifocais de substância branca

\footnotetext{
'Hospital das Clínicas da Faculdade de Medicina da Universidade de São Paulo, Departamento de Neurologia, São Paulo SP, Brazil. ${ }^{2}$ Hospital Santa Marcelina, Departamento de Neurologia, São Paulo SP, Brazil.

${ }^{3}$ Hospital das Clínicas da Faculdade de Medicina da Universidade de São Paulo, Instituto de Radiologia, São Paulo SP, Brazil.

Cesar Castello Branco LOPES (DD https://orcid.org/0000-0002-5731-2553; Sonia Maria Dozzi BRUCKI (D) https://orcid.org/0000-0002-8303-6732; Carlos Eduardo Borges PASSOS NETO (ID https://orcid.org/0000-0001-6350-188X; Luiza Alves CORAZZA (D) https://orcid.org/0000-0001-7866-7786; José Pedro Soares BAIMA (DD https://orcid.org/0000-0003-2708-1181; Matheus Dalben FIORENTINO (DD https://orcid.org/0000-0002-2996-9451; João Fellipe Santos TATSCH (D) https://orcid.org/0000-0002-6807-5004; Maria da Graça Morais MARTIN (D) https://orcid.org/0000-0002-1794-9146; Leandro Tavares LUCATO (D) https://orcid.org/0000-0001-9181-5245; Hélio Rodrigues GOMES (DD https://orcid.org/0000-0003-4461-0305; Maria Sheila Guimarães ROCHA (D) https://orcid.org/0000-0003-4312-3994; Ida FORTINI (D) https://orcid.org/0000-0003-1084-340X; Ricardo NITRINI (D) https://orcid.org/0000-0002-5721-1525; Luiz H. CASTRO (D) https://orcid.org/0000-0003-1878-8548

Correspondence: Cesar Castello Branco Lopes; E-mail:cesarcblopes@gmail.com, cesar.lopes@hc.fm.usp.br Conflict of interest: There is no conflict of interest to declare.
}

Author's contributions: All authors contributed to the study conception and design. Luiza Corazza, João Tatsch, Maria Rocha and Sonia Brucki contributed to the evaluation and data acquisition of patient 1. Cesar Lopes, Matheus Fiorentino, Carlos Neto, José Baima, Ida Fortini, Hélio Gomes, Ricardo Nitrini and Luiz Castro contributed to the evaluation and data acquisition patient 2. Maria Martin and Leandro Lucato contributed to interpretation and discussion of the neuroimaging findings. All authors contributed in writing the main manuscript, which was critically reviewed by all.

Received on August 27, 2020; Accepted on October 6, 2020. 
podem ocorrer em pacientes com COVID-19, possivelmente associadas a estados alterados de consciência. Estudos adicionais são necessários para determinar o processo fisiopatológico da infecção viral e dos estados inflamatórios e imunomediados na gênese das manifestações neurológicas causadas pela COVID-19.

Palavras-chave: Neurologia; Infecções por Coronavírus; Encefalite; Infecções do Sistema Nervoso Central; Doenças Desmielinizantes.

\section{INTRODUCTION}

There is growing evidence of neurological involvement associated with SARS-CoV-2 infection ${ }^{1,2}$. Immune-mediated neurological manifestations have been reported, including Guillain-Barré and Miller-Fisher syndromes, polyneuritis cranialis and acute demyelinating encephalomyelitis ${ }^{1,2,34}$. In addition, central nervous system (CNS) lesions and brain magnetic resonance imaging (MRI) abnormalities in COVID-19 patients are being increasingly recognized. Arterial occlusion and venous thrombosis related to a prothrombotic state have been reported ${ }^{1,2}$. Small case series have also described cortical signal abnormalities on fluidattenuated inversion recovery (FLAIR) images, cortical diffusion restriction, leptomeningeal enhancement, cortical blooming artifact, and diffuse white matter abnormalities ${ }^{5,6}$.

We describe two patients that presented white matter lesions, suggestive of an inflammatory-demyelinating process associated with a prolonged hypoactive encephalopathy related to severe COVID-19 infection and long intensive care unit (ICU) stay.
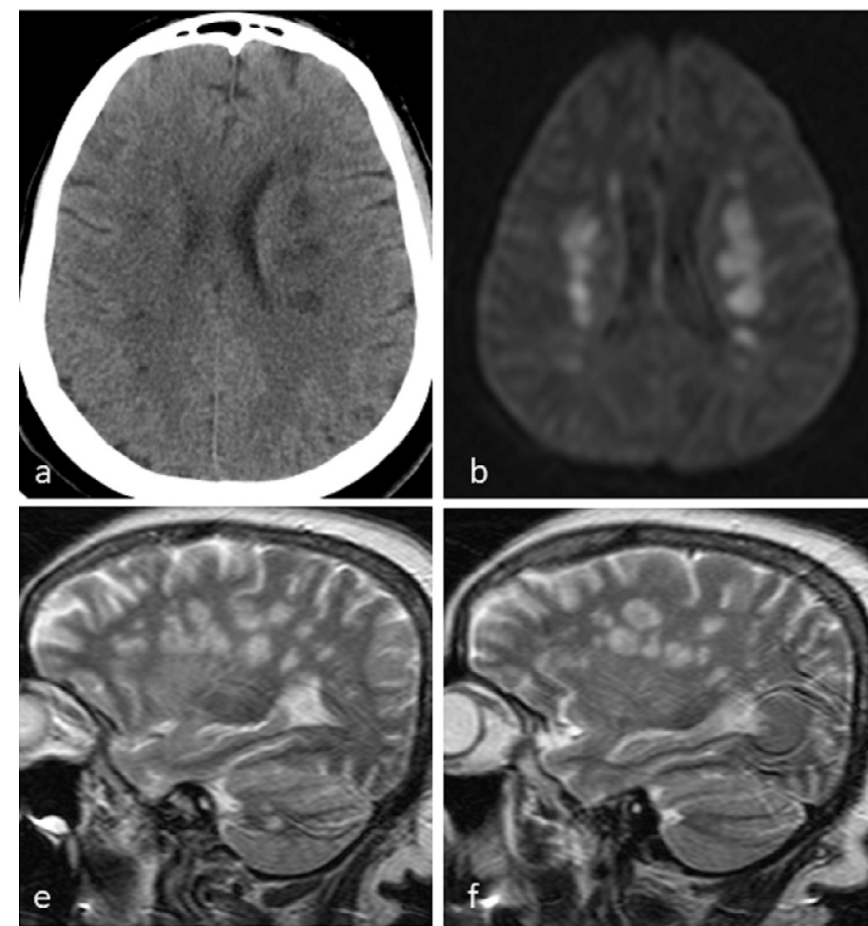

\section{PATIENT 1}

A 59-year-old woman with controlled mild arterial hypertension was admitted with a three-day history of cough, fever and dyspnea, progressing to respiratory failure requiring mechanical ventilation. Oropharyngeal swab polymerase chain reaction (PCR) was positive for SARS-CoV-2, and negative for influenza (H1N1). The patient received hydroxychloroquine and broad-spectrum antibiotics for ventilatorassociated pneumonia. After sedation discontinuation, the patient remained in an unconscious state. Neurological evaluation disclosed a patient in coma with asymmetric flexor motor responses (left more than right). Pupils were symmetric and reactive. Extraocular movements were normal. Deep tendon reflexes were hypoactive, with bilateral extensor plantar responses.

A non-contrast head computed tomography (CT) and magnetic resonance imaging (MRI) are shown in Figure 1. Cerebrospinal fluid (CSF) analysis was normal, oligoclonal bands and cultures were negative. PCR for SARS-CoV-2 in the
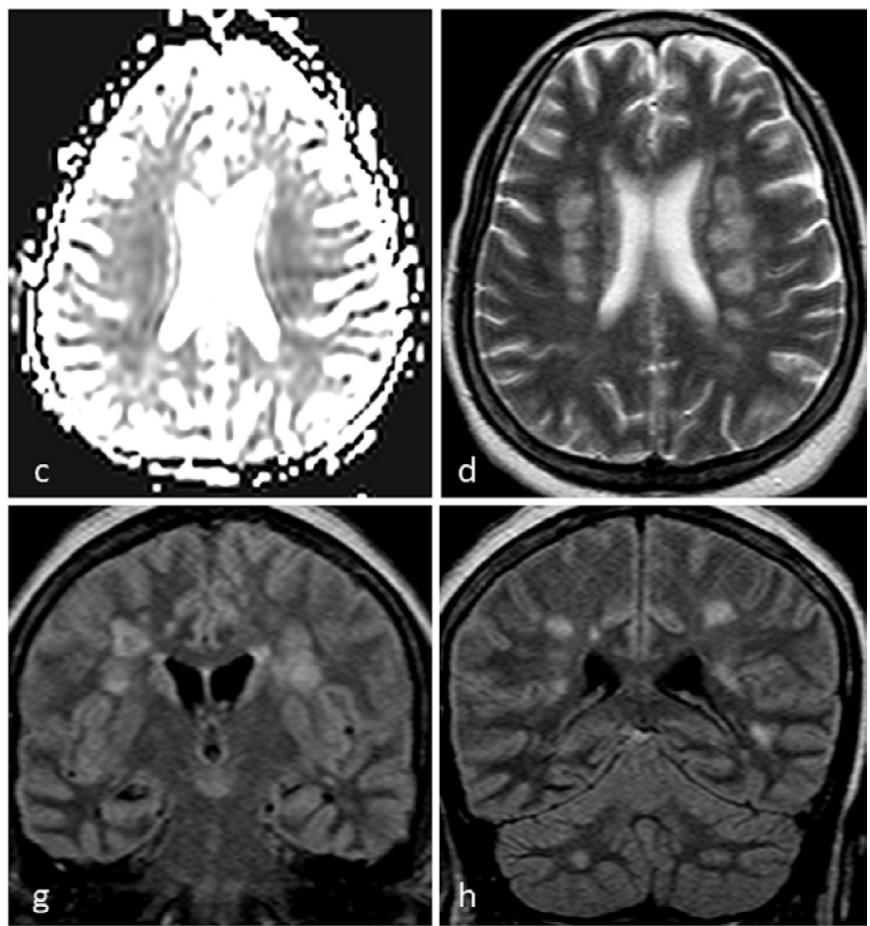

Figure 1. Multiple bilateral focal areas of signal abnormalities in the cerebral and cerebellar white matter, including corpus callosum (not shown). Axial computed tomography (CT) shows round foci of hypoattenuation in the centrum semiovale bilaterally (a), that also demonstrate high signal on diffusion-weighted imaging (DWI) (b) with areas of restricted diffusion on apparent diffusion coefficient (ADC) (c), and hyperintensity on axial T2-weighted images (d). Some of these lesions appear to have a perivenular dissemination on sagittal T2-weighted (e,f) and coronal fluid-attenuated inversion recovery (FLAIR) (g,h) images. There appears to be a "target" sign, with a low signal dot in the center of the lesion. There are also some lesions in the cerebellar white matter (e,h) and globus pallidus. 
CSF was negative. Electroencephalography (EEG) revealed diffuse slowing, without epileptiform discharges.

The patient's clinical condition worsened and she died of systemic complications associated with COVID-19.

\section{PATIENT 2}

A 41-year-old man presented to the emergency service with a six-day history of fever, rhinorrhea, progressive dyspnea, and was intubated due to respiratory failure. Medical history was remarkable for hypertension, diabetes, obesity and smoking. SARS-CoV-2 PCR was positive in tracheal aspirate specimens. After respiratory improvement, sedation and neuromuscular blocking, agents were weaned. Prolonged difficulty in awakening was attributed to acute renal failure. Renal replacement therapy was instituted. After ICU discharge (day 14), a neurology consult was required due to persistent decreased level of consciousness and four-limb weakness.

On neurological evaluation, the patient was awake, with spontaneous eye opening, but displayed blunted affect and poor verbal interaction with the examiner. Motor examination showed decreased spontaneous movement of the four limbs, with normal withdrawal response to pain, preserved deep tendon reflexes, and bilateral flexor plantar responses. Pupils were reactive to light, extraocular motor movements were normal, and the face was symmetrical.

Brain CT and MRI are depicted in Figure 2. Spinal cord MRI did not show abnormalities. CSF was normal, with negative microbiologic analysis and absent oligoclonal bands. CSF PCR for SARS-CoV-2 was negative. EEG showed diffuse slowing, without epileptiform abnormalities. Nerve conduction and needle studies showed a moderate subacute sensorimotor polyneuropathy.

After two weeks, mental status evaluation disclosed a fully alert and cooperative patient, with mild attentional and executive dysfunction.

\section{DISCUSSION}

We describe two cases of severe COVID-19 with prolonged ICU stay and delayed awakening that presented with neurological impairment and bilateral multifocal white matter lesions on MRI.

The neurotrophic potential of the coronaviruses has been widely recognized since the original descriptions ${ }^{7}$. SARS-CoV-2 potential to cause neurological damage has been rapidly recognized as the present epidemic unfolded.
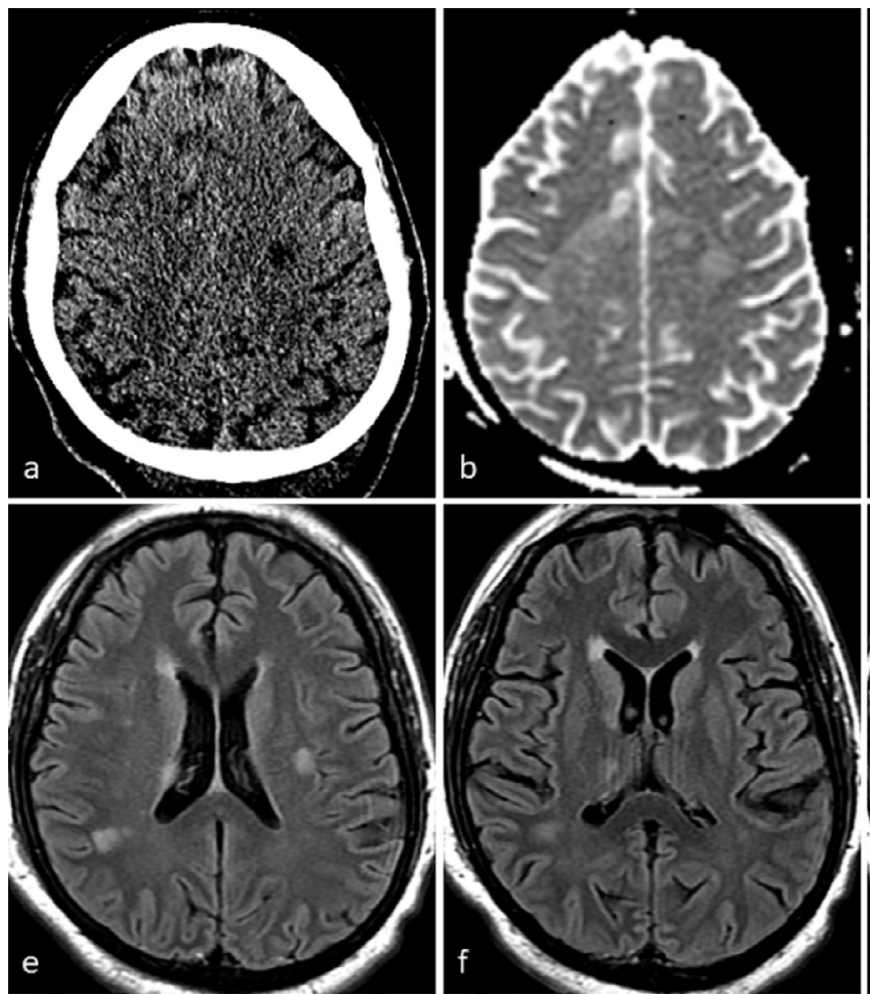
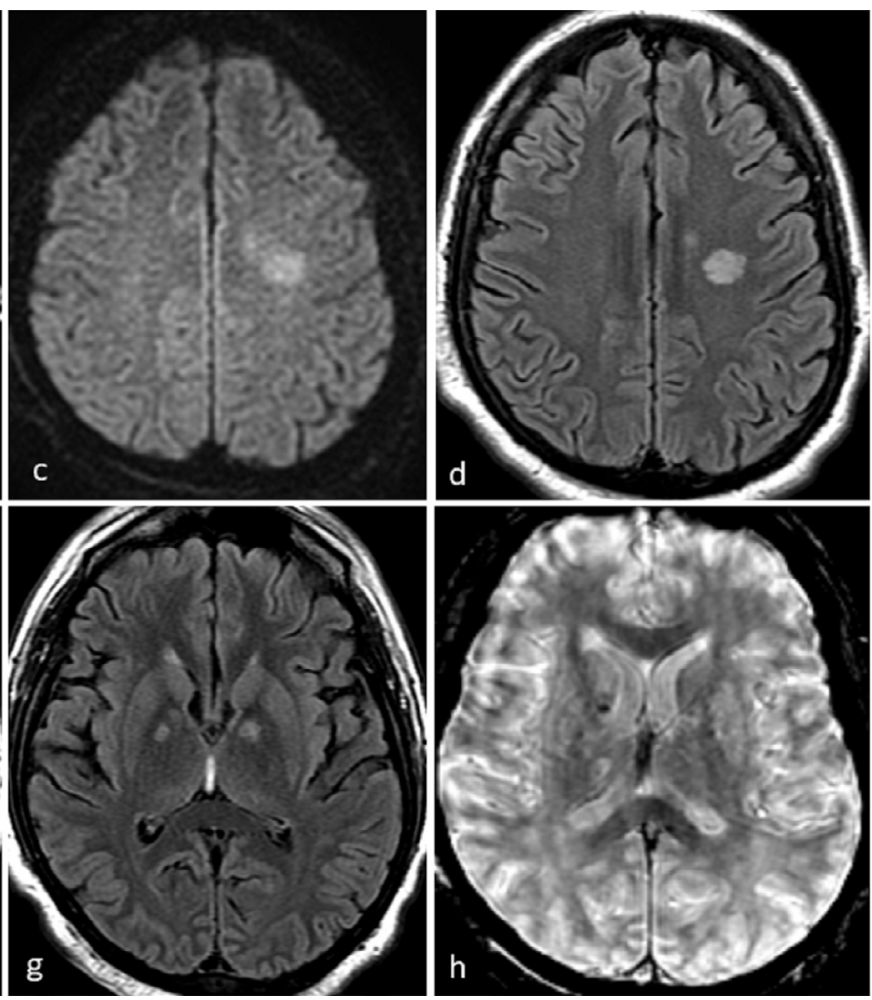

Figure 2. Focal lesions located in the centrum semiovale, bilaterally (a,b,c,d,e), right thalamus (f,h), globus pallidus bilaterally (g), and anterior limb of internal capsule (f,g,h), characterized by hyperintensity on axial fluid-attenuated inversion recovery (FLAIR) images (d,e,f,g), high signal on diffusion-weighted imaging (DWI) (c) and apparent diffusion coefficient (ADC) (b), representing diffusion facilitation. Noncontrast CT demonstrates hypoattenuating areas (a). Only one lesion, located in the anterior limb of the internal capsule, was hypointense on susceptibility-weighted angiography (SWAN) (h), suggestive of a hemorrhagic focus. Another lesion in the left centrum semiovale shows perivascular topography (c,d). 
SARS-CoV-2 may reach the brain via bloodstream or transcribriform route along the olfactory nerve ${ }^{1,8}$. The virus invades neurons through angiotensin-converting enzyme-2 (ACE-2) receptors. Most of SARS-CoV-2 neurological manifestations are thought to occur in late stages of the infection, possibly associated with immune response ${ }^{8}$.

Neurological manifestations and neuroimaging findings in our cases could be caused by ischemic injuries, by a direct encephalitic viral effect, by toxic-metabolic insults or by an acute demyelination process. MRI diffusion images did not display diffusion restriction that resembles a vascular pattern, rendering ischemia unlikely. Additionally, CSF analysis was not suggestive of an infectious process, neurological impairment was not present in the acute phase of the infection, and neuroimaging findings were not characteristic of classical toxic and metabolic disorders, making the first three elicited mechanisms unlikely. The finding of bilateral periventricular relatively asymmetrical lesions associated with deep white matter involvement is suggestive of an acute demyelination process.

We considered both cases compatible with the diagnosis of acute disseminated encephalomyelitis (ADEM) related to COVID-19 disease, since the clinical presentation was encephalopathy and neuroimaging displayed multifocal white matter abnormalities. Other clinical clues favoring this diagnosis are: prior confirmed acute viral infection, unremarkable CSF study excluding CNS infection, negative oligoclonal bands and lack of previous history of demyelinating diseases, such as multiple sclerosis, in both patients.

$\mathrm{ADEM}$ is an acute inflammatory CNS demyelinating condition precipitated by viral infection or, more rarely, vaccination, and is characterized by encephalopathy and multifocal neurologic deficits ${ }^{9,10}$. Given the lack of specific biomarkers or confirmatory tests, the diagnosis of ADEM is based on combined clinical and radiological features and exclusion of other possible similar conditions ${ }^{9,10}$. In children, in whom ADEM is more frequently encountered, current diagnosis criteria require the presence of encephalopathy, multifocal CNS events, and acute MRI abnormalities ${ }^{10,11}$. Specific criteria for ADEM in adults have not been established. Due to lower incidence in adults, ADEM is less studied in this population. The largest study comparing ADEM in different age groups showed that, in adults, disease course was more aggressive, and outcomes were poorer than in children ${ }^{12}$.

MRI is the preferred neuroimaging modality in patients with suspected ADEM, since head CT can be normal or display non-diagnostic features. In these cases, brain MRI typically displays bilateral and asymmetric T2/FLAIR hyperintensities in central and subcortical white matter ${ }^{9,10}$, that may also be present in cortical gray-white matter junction, thalami, basal ganglia, cerebellum, and brainstem. Heterogeneous findings are frequently encountered. Up to one third of patients may present gadolinium-enhancing lesions, and up to one third may present spinal cord involvement ${ }^{9}$. Restricted diffusion in diffusion-weighted imaging (DWI) sequences can be present in acute settings, and has been associated with a more aggressive disease course ${ }^{13}$.

ADEM has already been reported in endemic coronavirus subtypes, in previous coronavirus outbreaks ${ }^{14,15}$. In 2004, a 15-year-old boy presented cerebellar and spinal cord demyelinating lesions, with a preceding history of upper respiratory tract illness. Coronavirus OC43 was detected by CSF PCR and in nasopharyngeal secretions ${ }^{14}$. In 2015, a case report described a patient with slow awakening after prolonged ICU stay due to MERS-CoV infection, in whom brain MRI identified bilateral multifocal white matter lesions. The authors related those findings to ADEM, rather than to encephalitis, due to direct viral neuroinvasion, since CSF analysis disclosed negative PCR for MERS-CoV ${ }^{15}$.

Demyelinating lesions after viral infection can be caused by cross-reaction between immune response and host cell components, as well as by lymphocyte and macrophage reaction and lymphokine-mediated damage, and immune cell protease release ${ }^{16}$. Pro-inflammatory state in COVID-19 is associated with increased cytokines ("cytokine storm") that may activate glial cells, leading to demyelination ${ }^{17,18}$. Additionally, viral infection can trigger the production of antibodies targeted against glial cells ${ }^{18}$. In primates, murine coronavirus can acutely replicate and cause oligodendrocyte lysis and demyelination ${ }^{19}$.

Perivenular sleeves of demyelination associated with inflammatory infiltrates are the hallmark of ADEM pathology ${ }^{9}$. Eventually, larger areas of demyelination may occur secondary to coalescence of perivenous demyelinating lesions. Post-mortem neuropathological findings in one COVID-19 patient revealed features suggestive of combined demyelinating and vascular mechanisms. Additionally, hemorrhagic white matter lesions, clusters of macrophages associated with axonal injury and ADEM-like appearance were also found in subcortical white matter ${ }^{20}$.

We found three single case reports of suspected COVID19 infection related to $\mathrm{ADEM}^{3,21}$. The first described case reports a woman in the forties presenting with encephalopathy and bulbar involvement nine days after exhibiting COVID-19 symptoms, in whom MRI revealed white matter lesions suggestive of a demyelinating process ${ }^{3}$. The second case describes a 64-year-old woman with optic neuritis and myelitis with corresponding enhancing lesions on MRI three weeks after an influenza-like syndrome. The patient had positive serum IgG for SARS-CoV-2, and negative anti-AQ4 and anti-MOG antibodies ${ }^{21}$. Both of these cases occurred in outpatients with mild COVID-19 presentation, contrary to what we have reported in our two cases. Despite the differences in clinical presentation, MRI findings in the first case are similar to those in our patients.

The third case report ${ }^{22}$ describes a 51-year-old woman with severe COVID-19 who remained in coma after sedation 
withdrawal, with impaired oculocephalic response to the left. Brain MRI showed bilateral deep hemispheric and juxtacortical white matter lesions, with restricted diffusion. CSF analysis was normal, with negative PCR for SARS-CoV-2. Subsequent MRIs obtained during hospitalization showed increasing lesions associated with decreased restricted diffusion. The patient was treated with methylprednisolone and intravenous immunoglobulin (IgIV), and gradually improved.

In a case series ${ }^{23}$, ADEM was related to severe COVID19 infection requiring long ICU stay in three patients. Two of these presented with post-extubation encephalopathy characterized by unresponsiveness. Brain MRI in the three cases showed multifocal lesions predominantly distributed in the white matter, many of which displayed diffusion restriction. CSF showed only mild protein elevation, and CSF PCR for SARS-CoV-2 was negative in all cases. COVID-19 infection severity in this case series is similar to that found in our cases, with prolonged mechanical ventilation and ICU stay ${ }^{23}$.

The largest COVID-19-associated ADEM series to date describes 43 patients with COVID-19-related neurological disorders, nine of whom were classified within the ADEM spectrum, with a broad range of clinical and radiological presentations ${ }^{4}$. None of the five tested patients presented positive for SARS-CoV-2 in the CSF. Four of the nine patients presented with critical or severe COVID-19 infection; in three the initial neurological symptom was slow awakening in the ICU; eight underwent immunotherapies. Only one patient presented a complete recovery, seven were showing improvement by the time the article was published, and one died. A neuropathological specimen obtained in a patient that underwent hemicraniectomy revealed findings supportive of ADEM; SARS-CoV-2 was not identified in brain tissue. All patients presented multifocal supratentorial white matter lesions, and two also disclosed intraspinal lesions ${ }^{4}$.

The main characteristics of the three patients with slow awakening in ICU in that series ${ }^{4}$ resemble those of the two patients presented here. These patients had more than two weeks of ICU stay, presented with severe respiratory distress due to confirmed COVID-19 infection, PCR for SARS-CoV- 2 in CSF was negative in the tested ones, and MRI depicted multifocal areas of white matter lesions, some with hemorrhagic features. Additionally, one of these patients showed ongoing improvement with supportive treatment alone, similarly to patient 2 .

Treatment of ADEM consists of immunotherapies, such as intravenous pulse methylprednisolone, plasma exchange and IgIV. There are no randomized controlled trials related to ADEM. Use of high-dose intravenous corticosteroids is widely accepted as first-line therapy, and was associated with substantial clinical improvement in adults in uncontrolled observational studies ${ }^{9,10}$. In patients who fail to respond to corticosteroids, IgIV and, less commonly, plasma exchange are considered second-line options ${ }^{24}$. In COVID-19 patients immunotherapy should be individualized, taking into account concerns about safety of these treatments.

COVID-19 infection-related ADEM described in the current literature presents heterogeneous clinical and neuroimaging findings. We have encountered reports that point to increasing ADEM diagnoses in a subgroup of patients that present with marked encephalopathy and disorders of consciousness after prolonged mechanical ventilation and ICU stay due to severe COVID-19 infection. The pathophysiology of this pattern of CNS lesions related to these conditions remains incompletely understood. An attractive explanation would be of an immune-mediated inflammatory reaction associated with the viral infection. Further studies should help elucidate the role of the viral infection, and of COVID-19-associated inflammatory states in the pathogenesis of brain lesions in this clinical setting.

These two reported cases highlight the importance of a careful neurological evaluation, followed by adequate neuroimaging, preferably MRI, in SARS-CoV-2 patients with delayed awakening after ICU stay. Disorders of consciousness are frequently attributed to toxic-metabolic encephalopathy. In this setting, brain lesions can be missed, unless patients undergo brain imaging studies.

The neurological impairment caused by ADEM may have a negative impact on long-term neurologic deficits, functional outcomes and mortality of patients with severe COVID-19 infections. Health professionals should be trained to promptly recognize neurologic manifestation in COVID-19 patients, allowing an early diagnosis of potentially treatable conditions, and possibly minimizing neurological sequelae of COVID-19 infection.

\section{References}

1. Ellul MA, Benjamin L, Singh B, Lant S, Michael BD, Easton A, et al. Neurological associations of COVID-19. Lancet Neurol. 2020 Jul;19(9):767-83. https://doi.org/10.1016/s1474-4422(20)30221-0

2. Munhoz RP, Pedroso JL, Nascimento FA, Almeida SM, Barsottini OGP, Cardoso FEC, et al. Neurological complications in patients with SARS-CoV-2 infection: a systematic review. Arq Neuropsiquiatr. 2020 May;78(5):290-300. https://doi.org/10.1590/0004-282×20200051
3. Zhang T, Rodricks MB, Hirsh E. COVID-19-associated acute disseminated encephalomyelitis: a case report. Neurocrit Care. 2020 AprOct; 1-7. https://doi.org/10.1007/s12028-020-01119-7

4. Paterson RW, Brown RL, Benjamin L, Nortley R, Wiethoff S, Bharucha T, et al. The emerging spectrum of COVID-19 neurology: clinical, radiological and laboratory findings. Brain. 2020 Oct;143(10):310420. https://doi.org/10.1093/brain/awaa240 
5. Helms J, Kremer S, Merdji H, Clere-Jehl R, Schenck M, Kummerlen C, et al. Neurologic Features in Severe SARS-CoV-2 Infection. N Engl J Med. 2020 Jun;382(23):2268-70. https://doi.org/10.1056/nejmc2008597

6. Kandemirli SG, Dogan L, Sarikaya ZT, Kara S, Akinci C, Kaya D, et al. Brain MRI Findings in Patients in the Intensive Care Unit with COVID-19 Infection [published online ahead of print, 2020 May 8]. Radiology. 2020 May;297(1):E232-5.. https://doi.org/10.1148/radiol.2020201697

7. Mclntosh K, Becker WB, Chanock RM. Growth in suckling-mouse brain of "IBV-like" viruses from patients with upper respiratory tract disease. Proc Natl Acad Sci U S A. 1967 Oct;58(6):2268-73. https:// doi.org/10.1073/pnas.58.6.2268

8. Panciani PP, Saraceno G, Zanin L, Renisi G, Signorini L, Battaglia L, et al. SARS-CoV-2: "Three-steps" infection model and CSF diagnostic implication. Brain Behav Immun. 2020 Jul;87:128-9. https://doi. org/10.1016/j.bbi.2020.05.002

9. Pohl D, Alper G, Van Haren K, Kornberg AJ, Lucchinetti CF, Tenembaum S, et al. Acute disseminated encephalomyelitis: Updates on an inflammatory CNS syndrome. Neurology. 2016 Aug;87(9 Suppl 2):S38-45. https://doi.org/10.1212/wnl.0000000000002825

10. Cole J, Evans E, Mwangi M, Mar S. Acute Disseminated Encephalomyelitis in Children: An Updated Review Based on Current Diagnostic Criteria. Pediatr Neurol. 2019 Jul;100:26-34. https://doi. org/10.1016/j.pediatrneurol.2019.06.017

11. Krupp LB, Tardieu M, Amato MP, Banwell B, Chitnis T, Dale RC, et al. International Pediatric Multiple Sclerosis Study Group criteria for pediatric multiple sclerosis and immune-mediated central nervous system demyelinating disorders: revisions to the 2007 definitions. Mult Scler. 2013 Apr;19(10):1261-7. https://doi. org/10.1177/1352458513484547

12. Ketelslegers IA, Visser IE, Neuteboom RF, Boon M, CatsmanBerrevoets CE, Hintzen RQ. Disease course and outcome of acute disseminated encephalomyelitis is more severe in adults than in children. Mult Scler. 2011 Dec;17(4):441-8. https://doi. org/10.1177/1352458510390068

13. Kamr, W.H., Tantawy AM, Moustafa M, Adb-Elsalam OA. Acute disseminated encephalomyelitis: MR Diffusion weighted imaging: Potential diagnostic value and outcome predilection. The Egyptian Journal of Radiology and Nuclear Medicine, 2017 Mar;48(1):215-23. https://doi.org/10.1016/j.ejrnm.2017.01.004.

14. Yeh EA, Collins A, Cohen ME, Duffner PK, Faden H. Detection of coronavirus in the central nervous system of a child with acute disseminated encephalomyelitis. Pediatrics. 2004 Jan;113(1 Pt 1):e73-6. https://doi.org/10.1542/peds.113.1.e73
15. Arabi YM, Harthi A, Hussein J, Bouchama A, Johani S, Hajeer AH, et al. Severe neurologic syndrome associated with Middle East respiratory syndrome corona virus (MERS-CoV). Infection. 2015 Jan;43(4):495501. https://doi.org/10.1007/s15010-015-0720-y

16. Barac-Latas V, Suchanek G, Breitschopf H, Stuehler A, Wege H, Lassmann H. Patterns of oligodendrocyte pathology in coronavirusinduced subacute demyelinating encephalomyelitis in the Lewis rat. Glia. 1997 Dec;19(1):1-12. https://doi.org/10.1002/(sici)10981136(199701)19:1\%3C1::aid-glia1\%3E3.0.co;2-5

17. Mehta P, McAuley DF, Brown M, Sanchez E, Tattersall RS, Manson JJ, et al. COVID-19: consider cytokine storm syndromes and immunosuppression. Lancet. 2020 Mar;395(10229):1033-4. https:// doi.org/10.1016/s0140-6736(20)30628-0

18. Caso F, Costa L, Ruscitti P, Navarini L, Del Puente A, Giacomelli $\mathrm{R}$, et al. Could Sars-coronavirus-2 trigger autoimmune and/or autoinflammatory mechanisms in genetically predisposed subjects? Autoimmun Rev. 2020 May;19(5):102524. https://doi.org/10.1016/j. autrev.2020.102524

19. Murray RS, Cai GY, Hoel K, Zhang JY, Soike KF, Cabirac GF. Coronavirus infects and causes demyelination in primate central nervous system. Virology. 1992 May;188(1):274-84. https://doi.org/10.1016/00426822(92)90757-G

20. Reichard RR, Kashani KB, Boire NA, Constantopoulos E, Guo Y, Lucchinetti CF. Neuropathology of COVID-19: a spectrum of vascular and acute disseminated encephalomyelitis (ADEM)-like pathology. Acta Neuropathol. 2020 May;140(1):1-6. https://doi.org/10.1007/ s00401-020-02166-2

21. Novi G, Rossi T, Pedemonte E, Saitta L, Rolla C, Roccatagliata L, et al. Acute disseminated encephalomyelitis after SARS-CoV-2 infection. Neurol Neuroimmunol Neuroinflamm. 2020 Jun;7(5):e797. https:// doi.org/10.1212/nxi.0000000000000797

22. Parsons T, Banks S, Bae C, Gelber J, Alahmadi H, Tichauer M. COVID19-associated acute disseminated encephalomyelitis (ADEM). J Neurol. 2020 May;267(10):2799-802. https://doi.org/10.1007/ s00415-020-09951-9

23. McCuddy M, Kelkar P, Zhao Y, Wicklund D. Acute Demyelinating Encephalomyelitis (ADEM) in COVID-19 infection: A Case Series.2020 Sep-Oct;68(5):1192-5. https://doi.org/10.1101/2020.07.15.20126730.

24. Marchioni E, Marinou-Aktipi K, Uggetti C, Bottanelli M, Pichiecchio A, Soragna D, et al. Effectiveness of intravenous immunoglobulin treatment in adult patients with steroid-resistant monophasic or recurrent acute disseminated encephalomyelitis. J Neurol. 2002 Jan;249(1):100-4. https://doi.org/10.1007/PL00007836 